be able to develop under exactly similar conditions, providing a basis from which biological and physicochemical conditions may be varied for experimental purposes. In order to analyse food requirements, for example, jars to which food organisms and solutions of different kinds are added, and which are supplied with sea-water filtered through a porcelain candle filter, may be set up for comparison with the arrangement previously described.
This apparatus has been found to give a sufficient approximation to 'normal' conditions to enable larvæ to be reared through the most critical stages of development, while in use at the Beaufort, N.C., station of the U.S. Bureau of Fisheries, this summer. My acknowledgments are due to the Bureau and to Dr. Herbert F. Prytherch, director of the Station, for hospitality and advice accorded to me during the time when I was making use of it there.

\title{
Archæological Research in Western China
}

\begin{abstract}
$A^{\text {LTHOUGH archæological research in China has }}$ $A$ not yet afforded confirmation of the annals of the third millennium B.C., with which its recorded traditions open, excavation in the north and centre has brought to light not only cultures of the neolithic and bronze ages, but also inscriptions in a primitive script, which in a measure corroborate tradition and justify the attribution of authenticity to the dynasty of a period of some centuries before that of Cheo (1122 в.c.), hitherto regarded as the earliest dynastic record worthy of any degree of credence. The west must now be added to the regions of China in which archæological research has produced not only evidence of early civilisation, but also corroboration of a record which stands in a different category.
\end{abstract}

Recent excavations at Hanchow (J. West China Border Research Society, 6, 1933-34) point to an early cultural connexion of the west of China with the north and centre, which may even go back to a much earlier date, if, as is suggested by an eminent Chinese scholar, Dr. Ko Mo Jo, an inseription on bone tablets from Anyang, which records the appearance of men of Shuh in the fighting ranks, and belongs to the Yin dynasty (1400-1122 B.c.), may be taken to refer to Szechwan, of which the ancient name is Shuh. For the fortunate result by which this important addition has been made to knowledge of the prehistoric cultures of China, archæology is indebted to members of the West China Border Research Society, and more especially to Dr. David Graham, curator of the West China Union University Museums, who intervened at a crucial moment to guide the zeal of the Chinese authorities for excavation into channels which would ensure the scientific value of the investigation.

The excavation at Hanchow is one only of a number of activities in which the West China Border Research Society, which was founded in 1922, acting in close co-operation with the Union University, is promoting the advancement of scientific research in the extremely interesting and important border area of western China and eastern Tibet. Its headquarters at Chengtu serve as a focusing point for activities in geographical exploration and studies in anthropology, botany, zoology and medical science, which carry on the scientific work of members of the missionary bodies, who promoted the West China Union University. By their own researches and by their co-operation with members of other scientific expeditions, they did much to promote scientific knowledge of this region long before the University came into being in 1910. The University Museums, which now have 53,334 specimens, distributed among the three Museums of Archæology, Art and Ethnology, the Natural History Museum and the Museum of Medical and Dental Sciences, owe much to their efforts, especially in the ethnographical section, which contains material such as eannot be found in any other museum. The Society's journal, now in its sixth volume, contains much valuable matter, especially worthy of regard in the anthropological world, as the Society, both in its publications and in the organisation of research among its members, is bound in the terms of its constitution to concentrate on regional and other investigations which bear on problems relating to the little-known non-Chinese peoples of the area.

As regards the excavations at Hanchow referred to above, the accidental discovery in 1931 of stone and jade rings, knives, discs and other objects in a pit at T'ai-p'ing-ch'ang, eighteen $l i$ from Hanchow, when an irrigation ditch was being deepened, pointed to the possibility of a prehistoric burial, which was confirmed by systematic excavation in 1934. In addition to the original pit, the ground immediately surrounding was carefully explored and several points in the area were also tested. No further grave pits were found, but everywhere there was abundant material which appeared to be mainly the refuse from a group of ancient pottery kilns.

The preliminary account of the excavation includes also an analysis of the physical characters of the jade and stone objects by Prof. D. S. Pye and of the pottery by Prof. H. B. Collier. A comparison of the culture with that found at Yang Shao and Anyang in Honan and that from Sha Kuo T'un in Fengtien points to interesting resemblances as well as differences. Thus there is no painted pottery at Hanchow or Sha Kuo T'un such as was found by Dr. J. G. Andersson at Yang Shao. Both the Han. chow and the Yang Shao cultures have large and small stone axes, chisels, knives, pestles or hammers, and flat discs, and both incised and cord-marked pottery. In both the potter's wheel is known. At neither, nor at Sha Kuo T'un, is there metal; whereas at Anyang there is abundant bronze, associated with a primitive writing on bone, bone implements and painted pottery.

Though Yang Shao and Sha Kuo T'un are classed as neolithic, the use of the wire saw at Hanchow and resemblances to Cheo objects suggest that the Hanchow site is later than æneolithic. In all probability it cannot be later than the beginning of the Cheo dynasty (1122 B.C.); but it is almost certainly later than the bronze culture of Anyang, which belongs to the Yin dynasty (1400-1122 B.c.). Thus it must represent a retarded development of the west. 